\title{
PENINGKATKAN HASIL BELAJAR PKN KELAS V MELALUI MODEL ACTIVE LEARNING (TIPE ROLE REVERSAL QUESTION) SDN 4 DOPLANG KECAMATAN JATI KABUPATEN BLORA
}

\author{
Ambar Susilo Murti \\ SDN 4 Doplang Kecamatan Jati/ Kabupaten Blora \\ UPTD TK/SD Kecamatan Jati/ Kabupaten Blora \\ ambar5215@gmail.com
}

\begin{abstract}
Constitution No. 20 of 2003, concerning Citizenship Education (PKN) is a compulsory subject for primary education, secondary, and compulsory subjects for higher education. The purpose of this study is to improve learning outcomes Civics using Active Learning Model Type Question Role Reversal in Class V SDN 4 Doplang Jati district of Blora. This research was a class action (classroom action research). The stages as follows: (1) planning, (2) implementation, (3) observation and (4) reflection. The result of research indicating that students who received grades $\geq 70$ the first cycle increased by $25 \%$ from the initial $44 \%$ to $69 \%$. Then students who scored $\geq 70$ on the second cycle increased $28 \%$ to $97 \%$. The average value of the first cycle increased by $8.75 \%$ from 66.53 into 75.28 early in the first cycle and then the second cycle of the average value increased again by $10.97 \%$ to 86.25 . Researchers suggest teachers should encourage students to be more daring in expressing opinions, questions and ideas that are not held only in Civics alone but on other subjects. In addition, teachers are expected to use active learning model of the type of role reversal question in improving student learning outcomes in other subjects. As for the school is expected to provide training to teachers on implementing learning activities are innovative and creative. Keywords: active learning, civic education, learning outcomes.
\end{abstract}

\begin{abstract}
ABSTRAK
Undang-Undang Nomor 20 Tahun 2003, tentang Pendidikan Kewarganegaraan (PKn) merupakan mata pelajaran wajib untuk jenjang pendidikan dasar, menengah, dan mata kuliah wajib untuk pendidikan tinggi. Tujuan penelitian ini adalah meningkatkan hasil belajar PKn dengan menggunakan Model Active Learning Tipe Role Reversal Question pada siswa kelas V SDN 4 Doplang Kecamatan Jati Kabupaten Blora. Penelitian ini merupakan penelitian tindakan kelas (classroom action research). Adapun tahapannya sebagai berikut: (1) perencanaan, (2) pelaksanaan, (3) pengamatan dan (4) refleksi. Hasil penelitian menunjukkkan bahwa siswa yang memperoleh nilai $\geq 70$ pada siklus I meningkat sebesar $25 \%$ dari kondisi awal $44 \%$ menjadi $69 \%$. Kemudian siswa yang memperoleh nilai $\geq 70$ pada siklus II mengalami peningkatan $28 \%$ menjadi $97 \%$. Nilai rata-rata pada siklus I mengalami peningkatan sebesar 8,75\% dari kondisi awal 66,53 menjadi 75,28 pada siklus I kemudian pada siklus II nilai rata- rata mengalami peningkatan lagi sebesar 10,97\% menjadi 86,25. Peneliti menyarankan hendaknya guru dapat mendorong siswa agar lebih berani dalam mengemukakan pendapat, pertanyaan dan ide yang dimiliki tidak hanya dalam pelajaran PKn saja namun pada mata pelajaran yang lain. Selain itu, Guru diharapkan dapat menggunakan model active learning tipe role reversal question dalam meningkatkan hasil belajar siswa pada mata pelajaran lain. Adapun bagi pihak sekolah diharapkan memberikan pelatihan kepada guru tentang menerapkan kegiatan pembelajaran yang inovatif dan kreatif.
\end{abstract}

Kata Kunci: active learning, PKn, hasil belajar. 
190 | Premiere Educandum, Volume 6 Nomor 2, Desember 2016, 189 - 199

\section{A. PENDAHULUAN}

Pendidikan diselenggarakan melalui pemberdayaan semua komponen masyarakat melalui peran serta dalam penyelenggaraan dan pengendalian mutu layanan pendidikan. Menurut UndangUndang Nomor 20 Tahun 2003, pendidikan mempunyai andil penting dalam menentukan proses pencapaian tujuan pendidikan nasional yaitu mengembangkan potensi peserta didik agar menjadi manusia yang beriman dan bertaqwa kepada Tuhan Yang Maha Esa, berakhlak mulia, sehat, berilmu, cakap, kreatif, mandiri dan menjadi warga negara yang demokratis serta bertanggung jawab.

Selain itu, Undang-Undang Nomor 20 Tahun 2003, Pendidikan Kewarganegaraan (PKn) merupakan mata pelajaran wajib untuk jenjang pendidikan dasar, menengah dan mata kuliah wajib untuk pendidikan tinggi. Pada jenjang sekolah dasar PKn diajarkan kepada siswa yang berusia 7-12 tahun dimana menurut Piaget merupakan fase berkembangan operasional konkret.

Kenyataannya di kelas, dalam proses pembelajaran PKn di sekolah dasar siswa belum sepenuhnya terlibat secara langsung, seperti halnya yang terjadi pada kelas V SDN 4 Doplang Kecamatan Jati Kabupaten Blora. Kegiatan pembelajaran masih di dominasi oleh aktivitas guru yaitu dengan pengunaan metode ceramah saat menjelaskan materi pelajaran. Berdasarkan observasi yang dilakukan pada saat kegiatan pembelajaran PKn berlangsung, siswa tidak sepenuhnya memperhatikan penjelasan guru, dikarenakan bosan dengan aktivitas mendengarkan, sehingga pembelajaran PKn dirasa kurang menyenangkan bagi siswa.

Motivasi siswa kelas V SDN 4 Doplang Kecamatan Jati Kabupaten Blora dalam mengikuti pembelajaran PKn dalam kategori rendah. Hal ini terlihat saat berlangsungnya kegiatan belajar terdapat beberapa siswa yang membuat gaduh. Guru berulangkali mengkondisikan siswa yang gaduh untuk diam dan memperhatikan pembelajaran, namun hal tersebut tidak dihiraukan. Selain membuat gaduh saat pembelajaran PKn, ada beberapa siswa yang tidak 
mengerjakan tugas dengan sungguhsungguh, terkesan yang penting mengerjakan. Ketika selesai menjelaskan pembelajaran, guru memberikan tugas kepada siswa untuk mengerjakan soal, namun banyak siswa yang mengerjakannya dengan asal-asalan, karena mereka tidak mau membaca buku untuk menjawab soal.

Keadaan tersebut menimbulkan pemerolehan hasil belajar yang belum masimal. Rendahnya hasil belajar Pkn dapat dilihat dari data nilai semester I tahun ajaran 2016/2017. Rata-rata nilai PKn lebih rendah dibandingkan nilai Bahasa Indonesia dan IPS. Diketahui bahwa nilai ratarata Bahasa Indonesia 74 , IPS 68, dan PKn 66. Selain nilai rata-rata PKn rendah diperoleh data bahwa baru 18 siswa atau 50\% dari jumlah siswa yang belum memenuhi KKM yang ditentukan yaitu 65. Melihat jumlah siswa yang masih banyak memperoleh nilai dibawah kriteria ketuntasan dan rata-rata nilai $\mathrm{PKn}$ yang belum maksimal maka perlu dilakukan peningkatan hasil belajar PKn.
Sebagai salah satu alternatif solusi yang dapat ditempuh guru untuk meningkatkan kegiatan pembelajaran yaitu dengan mengunakan model pembelajaran yang bisa diterapkan di kelas. Model pembelajaran merupakan pedoman dan segala sesuatu yang dibutuhkan dalam kegiatan pembelajaran baik berupa sumber, bahan atau alat yang akan digunakan. Hal ini sesuai dengan pendapat Joyce dan Weil (Hamruni, 2011: 5) model pembelajaran adalah suatu perencanaan yang digunakan sebagai pedoman dalam merencanakan pembelajaran di kelas dan untuk menentukan perangkat-perangkat pembelajaran termasuk di dalamnya buku-buku, film, komputer, kurikulum, dan lain-lain.

Model pembelajaran yang dapat diterapkan di kelas yaitu model active learning atau model pembelajaran aktif. Active learning atau pembelajaran aktif merupakan model pembelajaran yang mengacu pada tujuan pembelajaran, melibatkan siswa, menggunakan seni, gerakan dan panca indera serta langkah dan kegiatan dalam 
192 | Premiere Educandum, Volume 6 Nomor 2, Desember 2016, 189 - 199

pembelajaran (Hollingsworth, Pat \&

Gina Lewis, 2008: 8-9). Sedangkan menurut Naswatul Lailah (2003: 25) pembelajaran aktif merupakan proses pembelajaran yang menitik beratkan pada aktifitas siswa baik yang bersifat fisik, mental, emosi maupun intelektual untuk mencapai tujuan pendidikan yang berhubungan dengan aspek kognitif, afektif dan psikomotorik.

Salah satu bentuk atau tipe model active learning adalah tipe role reversal question pada kegiatan belajar mengajar. Model active learning tipe role reversal question dapat diterapkan dalam pembelajaran PKn, karena diharapkan dapat mengaktifkan siswa terutama dalam kegiatan tanya jawab dengan bertukar peran. Siswa dapat berpartisipasi secara langsung, tidak hanya mendengarkan penjelasan materi yang disampaikan oleh guru namun juga berfikir kritis dalam tanya jawab mengenai materi pembelajaran yang diperlajari. Penerapan model active learning tipe role reversal question pada pembelajaran PKn, diharapkan dapat meningkatkan pemahaman materi yang dipelajari oleh siswa sehingga hasil belajar siswa meningkat.

\section{B. Jenis Penelitian}

Penelitian ini merupakan penelitian tindakan kelas (classroom action research). Menurut Suharsimi Arikunto,dkk (2007: 3) penelitian tindakan kelas merupakan suatu pencermatan dari kegiatan pembelajaran berupa tindakan yang sengaja dimunculkan dan terjadi pada sebuah kelas secara bersama. Adapun tujuan penelitian ini adalah untuk meningkatkan hasil belajar PKn menggunakan model active learning tipe role reversal question $\begin{array}{lllll}\text { kelas } & \mathrm{V} & \mathrm{SDN} & 4 & \text { Doplang }\end{array}$ Kecamatan Jati Kabupaten Blora.

Menurut Suharsimi Arikunto (2007: 16) penelitian tindakan kelas dilakukan sekurang-kurangnya dalam dua siklus tindakan yang berurutan. Ada beberapa ahli yang mengemukakan model penelitian tindakan, namun secara garis besar terdapat empat tahapan yang dilalui yaitu (1) perencanaan, pelaksanaan, (3) pengamatan dan (4) refleksi. Adapun desain penelitiannya sebagai berikut: 


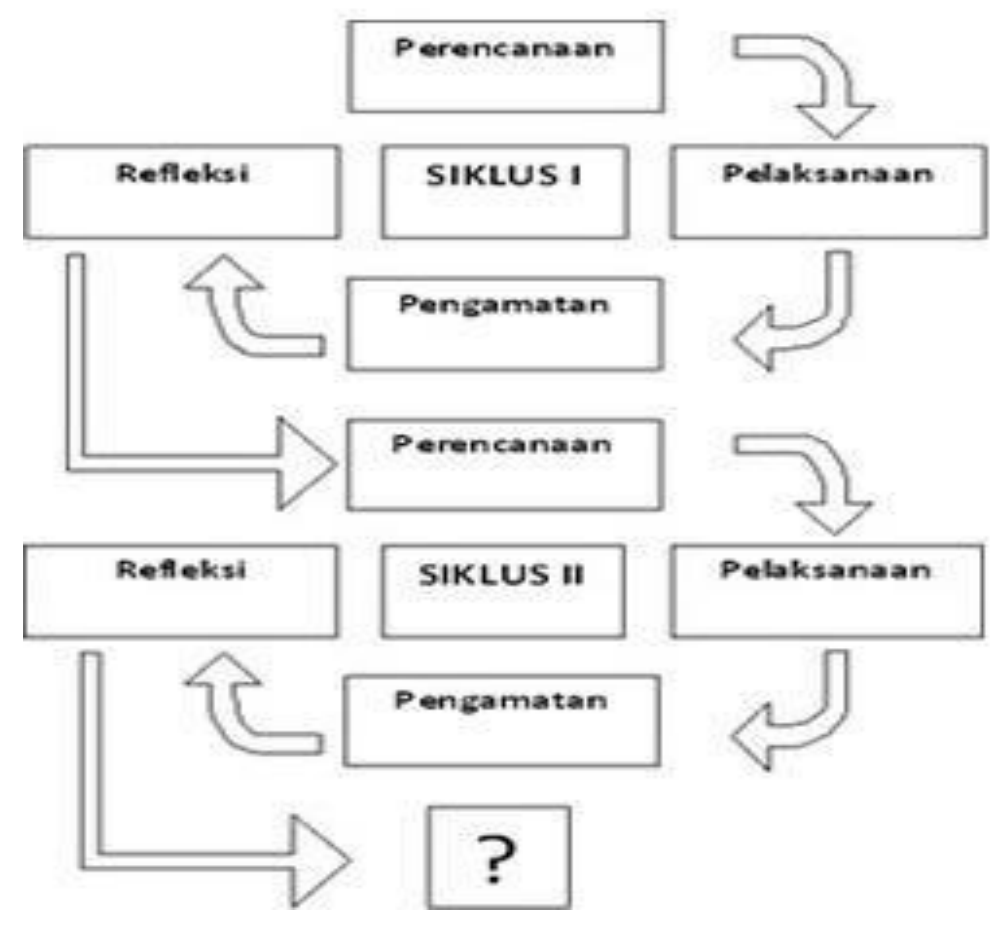

Gambar 1. Desain Penelitian Tindakan Kelas (Suharsimi, 2007: 16)

\section{HASIL PENELITIAN DAN PEMBAHASAN}

Pada tahap pra tindakan yang diberikan oleh 36 siswa, diperoleh nilai rata- rata hasil belajar sebesar 66,53. Jumlah siswa yang memperoleh nilai $\geq 70$ berjumlah 16 siswa atau $44 \%$, sedangkan 20 siswa atau 56\% dari jumlah siswa memperoleh nilai <70. Hal tersebut menunjukkan bahwa hasil belajar siswa untuk mata pelajaran PKn di SDN 4 Doplang Kecamatan Jati Kabupaten Blora masih cukup jauh dari target yang diharapkan. Untuk itu peneliti merasa perlu melakukan penelitian tindakan guna meningkatkan hasil belajar yang belum sesuai dengan harapan. Melihat hal tersebut, peneliti berusaha meningkatkan hasil belajar PKn pada siswa kelas V SDN 4 Doplang Kecamatan Jati Kabupaten Blora dengan menggunakan model active learning tipe role reversal question.

Pada siklus I terjadi peningkatan rata-rata hasil belajar sebesar $8,75 \%$ yaitu dari 66,53 pada kondisi awal menjadi 75,27. Jumlah siswa yang memperoleh nilai $\geq 70$ mengalami peningkatan sebesar $25 \%$ 
dari kondisi awal 44\% menjadi 69\%. Hal ini membuktikan bahwa tindakan pada siklus I memiliki pengaruh terhadap hasil belajar siswa pada mata pelajaran PKn.

Peningkatan hasil belajar siswa pada siklus I disebabkan oleh model active learning tipe role reversal question yang diterapkan oleh guru. Model active learning tipe role reversal question menekankan pada aktivitas tanya jawab dengan bertukar peran (Silberman Mel, 2007: 149). Pelaksanaan pembelajaran dimodifikasi dengan mempertimbangkan kemampuan dan kebutuhan siswa. Kegiatan pembelajaran diawali dengan guru menjelaskan rangkaian kegiatan pembelajaran termasuk aturan tanya jawab dengan bertukar peran. Guru membagi siswa menjadi beberapa kelompok untuk melakukan diskusi mengenai materi pelajaran. Kegiatan dilanjutkan dengan membuat pertanyaan individu agar pertanyaan yang muncul sesuai dengan materi yang dipelajari. Setelah siswa membuat pertanyaan individu kegiatan selanjutnya yaitu tanya jawab dengan bertukar peran. Guru memberikan umpan balik terhadap jawaban siswa.

Pelaksanaan pembelajaran PKn dengan menerapkan model active learning tipe role reversal question pada siklus I sudah berjalan dengan baik. Meskipun terdapat kekurangan yang perlu diperbaiki yakni pada aktivitas guru dalam menjelaskan kegiatan pembelajaran kepada siswa dan masih rendahnya aktivitas menjawab pertanyaan. Berdasarkan hasil pengamatan pada siklus I pertemuan pertama guru tidak menjelaskan kegiatan pembelajaran seperti adanya diskusi, membuat pertanyaan individu, dan melakukan pertukaran peran untuk tanya jawab pada awal kegiatan pembelajaran, namun pada saat siswa melakukan diskusi kelompok. Setelah melakukan apersepsi guru langsung membagi siswa dalam beberapa kelompok. Saat diskusi sedang berjalan, guru baru menjelaskan kegiatan belajar yang akan dilakukan. Hal tersebut menjadikan jalannya pembelajaran tidak terkondisi. Disaat melakukan diskusi kelompok, siswa harus mendengarkan penjelasan guru. Terdapat beberapa siswa yang tidak 
mendengarkan penjelasan guru sehingga setiap melanjutkan kegiatan lain guru menjelaskan kembali kegiatan pembelajaran yang akan dilakukan.

Dalam penerapan model active learning tipe role reversal question terdapat aktivitas siswa yang diamati dari awal kegiatan sampai akhir kegiatan pembelajaran dengan menggunakan instrument lembar pengamatan aktivitas siswa. Aktivitas yang diamati selama proses pembelajaran dibagi menjadi 4 aspek mulai dari kejasama, tanggung jawab, mengajukan dan menjawab pertanyaan. Berdasarkan hasil pengamatan pada siklus I aktivitas siswa dalam aspek kerjasama, tanggung jawab dan mengajukan pertanyaan sudah mencapai kriteria baik. Sedangkan aspek menjawab pertanyaan masih tergolong kurang. Aktivitas menjawab pertanyaan pada siklus I masih rendah karena beberapa siswa masih malu untuk mengacungkan tangan saat diberikan kesempatan menjawab. Selain itu, beberapa siswa takut jika salah menjawab pertanyaan.
Kendala yang muncul pada siklus I diperbaiki pada siklus II. Pada siklus II guru menjelaskan kegiatan pembelajaran sesuai dengan rencana pelaksanaan pembelajaran yaitu pada awal kegiatan. Setelah siswa mengerti, kegiatan selanjutnya baru dilakukan. Guru selalu membimbing dan mengarahkan siswa dalam kegiatan pembelajaran. Guru juga memberikan dorongan serta motivasi kepada siswa agar aktif dalam pembelajaran. Sesuai dengan pendapat Sugihartono dkk. (2007: 85), salah satu peran guru dalam kegiatan pembelajaran adalah sebagai motivator. Sebagai seorang motivator, guru dituntut untuk mampu mendorong siswanya agar senantiasa memiliki motivasi tinggi dan aktif dalam belajar. Dalam hal ini guru memberikan dorongan dan motivasi kepada untuk berani mengajukan pertanyaan serta menjawab pertanyaan pada saat kegiatan tanyajawab. Bagi siswa yang belum pernah menjawab pertanyaan diberi banyak kesempatan, agar tidak ada siswa yang dominan dalam menjawab pertanyaan. 
196 | Premiere Educandum, Volume 6 Nomor 2, Desember 2016, 189 - 199

Pelaksanaan kegiatan

pembelajaran pada siklus II yang dilakukan guru lebih baik daripada siklus I. Guru sudah menerapkan dan mengorganisasikan pembelajaran PKn menggunakan model active learning tipe role reversal question dengan lebih baik. Kegiatan siswa dalam pembelajaran lebih terkondisi dan berurutan sesuai dengan rencana pelaksanaan pembelajaran. Seluruh siswa sudah aktif dalam kegiatan pembelajaran.

Hasil pengamatan terhadap siswa pada siklus II menunjukkan bahwa siswa lebih aktif, senang dan bersemangat mengikuti pembelajaran. Setelah siswa mendengarkan penjelasan guru mengenai kegiatan yang dilakukan, siswa langsung berinisiatif sendiri berkumpul dengan kelompok masing-masing untuk berdiskusi dan menuliskan hasil diskusinya dengan baik pada lembar diskusi yang sudah disiapkan. Setelah selesai berdiskusi siswa langsung meminta lembar untuk membuat pertanyaan individu dan sangat antusias untuk melakukan tanya jawab dengan bertukar peran. Pada saat tanya jawab dengan bertukar peran guru memberikan reward bagi siswa yang menjawab pertanyaan dengan benar, sehingga siswa berlomba-lomba untuk mendapatkan reward paling banyak. Bagi siswa yang memberikan pertanyaan juga diberi penghargaan secara lisan sehingga siswa lain termotivasi untuk bertanya. Siswa yang belum benar dalam menjawab pertanyaan tidak disalahkan oleh guru, namun diberikan penjelasan mengenai jawaban yang benar. Siswa juga diberi kesempatan untuk menjawab pertanyaan lain dan tetap diberikan motivasi untuk tetap berani menjawab pertanyaan.

Pada siklus II pertemuan kedua terdapat kegiatan tambahan setelah melakukan diskusi kelompok yaitu mensimulasikan pemilihan ketua kelas. Setelah berdiskusi mengenai cara-cara pemilihan ketua kelas, siswa dibimbing guru untuk belajar mensimulasikan pemilihan ketua kelas dengan pemungutan suara secara langsung. Terdapat 2 calon ketua kelas, kemudian siswa melakukan pemungutan suara dengan mengacungkan jari, dengan 
ketentuan yang memperoleh suara terbanyak menjadi ketua. Kegiatan selanjutnya siswa ditugaskan untuk membuat pertanyaan dan melakukan pertukaran peran untuk tanya jawab. Pada kegiatan perputaran peran antusias siswa untuk mendapatkan reward sangat tinggi, setiap ada pertanyaan baik dari guru maupun siswa, hampir semua siswa mengacungkan jari untuk menjawab. Saat siswa menjadi guru siswa memberi pertanyaan namun guru tidak langsung menjawab, hal tersebut dilakukan untuk memberikan kesempatan bagi siswa lain menjawab pertanyaan, dan guru memberikan penguatan atas jawaban siswa. Seperti Siklus I, pada akhir pertemuan kedua Siklus II dilakukan evaluasi untuk melihat peningkatan hasil belajar siswa.

Hasil belajar siswa setelah dilakukan perbaikan tindakan pada siklus II mengalami kenaikan secara signifikan dari pra tindakan, siklus I dan sikus II. Nilai rata-rata hasil belajar siswa naik $8,75 \%$ dari kondisi awal 66,53 menjadi 75,27 pada siklus I, dan meningkat lagi $10,97 \%$ menjadi 86,25 pada siklus
II. Siswa yang memperoleh nilai $\geq 70$ meningkat $25 \%$ dari kondisi awal $44 \%$ menjadi $69 \%$ pada siklus I, dan meningkat lagi $28 \%$ menjadi $97 \%$ pada siklus II. Dengan demikian siklus II sudah mencapai kriteria keberhasilan tindakan yang ditentukan yaitu $75 \%$ dari jumlah siswa memperoleh nilai $\geq 70$, sehingga penelitian berhenti pada siklus II.

Peningkatan juga terjadi pada aktivitas siswa dalam penerapan model active learning tipe role reversal question pada mata pelajaran PKn. Aktivitas kerjasama pada siklus I $76 \%$ meningkat $19 \%$ menjadi $95 \%$ pada siklus II Aktivitas tanggung jawab pada siklus I $75 \%$ meningkat $22 \%$ menjadi $97 \%$ pada siklus II. Aktivitas bertanya pada siklus I $85 \%$ meningkat $8 \%$ menjadi $93 \%$ pada siklus II. Aktivitas menjawab pertanyaan pada siklus I 58\% meningkat $27 \%$ menjadi $85 \%$ pada siklus II.

\section{SIMPULAN DAN SARAN}

Berdasarkan hasil penelitian dan pembahasan dapat disimpulkan bahwa pembelajaran PKn mengunakan model active learning 
198 | Premiere Educandum, Volume 6 Nomor 2, Desember 2016, 189 - 199

tipe role reversal question dapat meningkatkan hasil belajar siswa kelas V SDN 4 Doplang Kecamatan Jati Kabupaten Blora. Langkahlangkah model active learning tipe role reversal question meliputi; guru membuat pertanyaan sesuai materi sebelum kegiatan pembelajaran dimulai, menjelaskan kegiatan pembelajaran, membagi siswa dalam beberapa kelompok, menugaskan siswa untuk melakukan diskusi kelompok, menugaskan siswa membuat pertanyaan individu, melakukan tanya jawab dengan bertukar peran dan memberikan umpan balik atas jawaban siswa.

Hal ini ditunjukkan dengan siswa yang memperoleh nilai $\geq 70$ pada siklus I meningkat sebesar $25 \%$ dari kondisi awal 44\% menjadi 69\%. Kemudian siswa yang memperoleh nilai $\geq 70$ pada siklus II mengalami peningkatan $28 \%$ menjadi $97 \%$. Nilai rata-rata pada siklus I mengalami peningkatan sebesar $8,75 \%$ dari kondisi awal 66,53 menjadi 75,28 pada siklus I kemudian pada siklus II nilai rata- rata mengalami peningkatan lagi sebesar $10,97 \%$ menjadi 86,25.
Peneliti menyarankan hendaknya guru dapat mendorong siswa agar lebih berani dalam mengemukakan pendapat, pertanyaan dan ide yang dimiliki tidak hanya dalam pelajaran PKn saja namun pada mata pelajaran yang lain. Hasil belajar PKn siswa telah mengalami peningkatan setelah diberi tindakan menggunakan model active learning tipe role reversal question, oleh karena itu disarankan kepada siswa agar mempertahankan dan lebih rajin belajar sehingga hasil belajar yang diperoleh selalu baik.

Selain itu, Guru diharapkan dapat menggunakan model active learning tipe role reversal question dalam meningkatkan hasil belajar siswa pada mata pelajaran lain. Adapun bagi pihak sekolah diharapkan memberikan pelatihan kepada guru tentang menerapkan kegiatan pembelajaran yang inovatif seperti model active learning tipe role reversal question. Sekolah juga menyediakan referensi buku tentang pembelajaran yang baik serta sarana penunjang lainnya sehingga guru memiliki wawasan pengetahuan, keterampilan, serta 
kreativitas dalam menerapkan modelmodel pembelajaran.

\section{DAFTAR RUJUKAN}

A.Ubaedillah \& Abdul Rozak. 2013. Pendidikan Kewarganegaraan (Civic Education): Pancasila, demokrasi, hak asasi manusia dan masyarakat madani. Jakarta: ICCE UIN Syarif Hidayatullah

Ari Samandhi. 2009. Pembelajaran Aktif (Active Learning). Jakarta: Teaching

Improvement Worshop Enginering Education Develompment Project.

Baharudin \& Esa Nur Wahyuni. 2009. Teori Belajar dan Pembelajaran. Yogyakarta: Ar-Ruzz Media.

Hiszyam Zaini. 2008. Strategi Pembelajaran Aktif. Yogyakarta: Insan Madani.

Hollingsworth, Pat \& Gina Lewis. 2008. Pembelajaran Aktif: Meningkatkan Keasyikan Kegiatan Di Kelas. Penerjemah: Dwi Wulandari. Jakarta: Indeks.

Muhammad Thobroni \& Arik Mustofa. 2013. Belajar \& Pembelajaran:

Pengembangan Wacana Dan Praktik Pembelajaran Dalam Pembangunan Nasional. Yogyakarta: Ar-Ruzz Media.

Nana Sudjana. 2011. Penilaian Hasil Proses Belajar Mengajar. Bandung: PT Remaja Rosda Karya.
Naswatul Lailah. 2003. Konsep Dasar Active Learning Dan Relevansinya Dengan Pengajaran Muhadatsah. Yogyakarta: Universitas Islam Negeri Yogyakarta.

Oemar Hamalik. 2006. Proses Belajar Mengajar. Bandung: Bumi Aksara.

Permendiknas No.22 Tahun 2006 tentang Standar Isi untuk Satuan Pendidikan Dasar dan Menengah Dasar.Diakses dari http://bnsp- indonesia. org/ $\mathrm{id} /$ ? page_id $=103$ pada tanggal 28 Januari 2016, jam 15.36 WIB.

.Silberman, Mel. 2007. Active Learning: $101 \quad$ Strategi Pembelajaran Aktif. Penerjemah: Sarjuli. Yogyakarta: Insan Madani.

Suharsimi, Arikunto. 2007. Penelitian Tindakan Kelas. Jakarta: Bumi Aksara.

$\begin{array}{crr}\text { Undang-Undang } & \text { Republik } \\ \text { Indonesia Nomor } & 20 \text { tahun } \\ 2003 & \text { Tentang } & \text { Sistem } \\ \text { Pendidikan } & \text { Nasional. } \\ \text { Yogyakarta: Pustaka Pelajar. }\end{array}$

